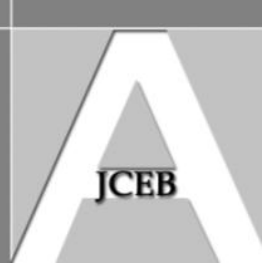

\title{
Applications of Extensive Green-roof Systems in Contributing to Sustainable Development in Densely Populated Cities: a Hong Kong Study
}

Vivian W. Y. Tam, (School of Engineering, University of Western Sydney, Australia)

Xiaoling Zhang, Winnie W. Y. Lee and L. Y. Shen, (Department of Building and Real Estate, The Hong Kong Polytechnic University, Hong Kong)

\begin{abstract}
Developed cities such as Hong Kong are usually densely populated. Since the land is limited, high-rise buildings are constructed. When buildings become higher, air flow is reduced and heat is trapped among high-rise buildings. The air temperature will be greatly increased and air pollution becomes a serious problem. To reduce air temperature caused by the wall-effects, various methods have been developed. One typical method is the use of green roof systems. The application of extensive green roofs on existing buildings has been recommended in Hong Kong since 2001. The advantage of this practice is that no additional floor area is required and it can also improve urban greenery. Although a green roof system has been introduced and adopted in Hong Kong since 2001, the emphasis is mainly given to the application of intensive green roofs for podium gardens instead of extensive green roofs. This paper investigates the current practice of using extensive green roofs in Hong Kong. The constraints in applying extensive green roofs are investigated, which leads to studying the solutions for mitigating these constraints and improving the future development of the implementation.
\end{abstract}

Keywords: Sustainable development, Extensive green roof, Intensive green roof, Benefit, Constraint, Recommendation, Hong Kong

\section{Introduction}

A green roof system is one of the typical methods for practicing sustainable development principles in the construction sector (Gedge and Frith 2004). It is considered an effective and important approach especially for those densely populated cities with major impacts on the local climate such as Hong Kong (Urbis Limited 2007).

Green roofs have been used since ancient times and the modern day green roofs evolved in Germany during 1950s (Jenrick 2005). Although the technique of applying green roof systems is well developed in European countries (Liu and Baskaran 2003), this is not the case for Hong Kong and many other countries. A green roof system has been greatly encouraged by the Hong Kong government since 2001. Recently, more projects have applied extensive green roofs in Hong Kong but mainly in governmental buildings and schools such as the New Electrical and Mechanical Services Department (EMSD) Headquarters and the Primary School at Sze Mei Street, San Po Kong. However, no guideline for the use of green roof systems has been introduced in Hong Kong (Urbis Limited 2007).

Therefore, this paper aims to:

- identify the differences between intensive green roofs and extensive green roofs;

- investigate the experiences of using green roofs in Hong Kong;

- explore the conditions and constraints of using extensive green roofs; and

- recommend solutions for reducing the constraints of applying the extensive green roofs. 


\section{Intensive Green Roofs Vs Extensive Green Roofs}

A green roof is a vegetated space where a layer of plant grows on top of a roof (Urbis Limited 2007). Green roofs can mainly be classified into two major types: (i) extensive green roofs; and (ii) intensive green roofs. The intensive green roof is a traditional-style roof garden. It consists mainly of large trees and shrubs. They are usually easily accessible to the public and may include some features similar to a park. It needs flat roofs. It is a labour intensive type of green roof requiring regular irrigation, maintenance and care (Worden et al. 2004). The extensive green roofs are usually inaccessible to the public but involve several environmental benefits such as mitigating storm water effects and protect building structures. It is heavy and requires structural inspection before construction to determine roof capacity and weight limit (Worden et al. 2004). Plants usually chosen for extensive green roofs include succulents and moss (Cutlip 2006).

When compared to extensive green roofs, intensive green roofs add a considerable weight to roofs (Cutlip 2006), they are more costly to build (Ngan 2004), often require irrigation and maintenance (Jenrick 2005), as well as deeper soil (Urbis Limited 2007). The intensive green roofs have thicker vegetation layers above the roof insulation, which is more suitable for different types and sizes of plants. More space needs to be provided for the plants to develop root systems. It requires a roof that can support its greater structural loads (Koppany 2002). The characteristics of the two types of green roofs is summarized in Table 1:

\begin{tabular}{|c|c|c|}
\hline Characteristics & Extensive green roof & Intensive green roof \\
\hline Weight & Lower & Greater \\
\hline Capital cost & Lower & Higher \\
\hline Maintenance & Minimal & Higher \\
\hline Soil depth & $50 \mathrm{~mm}$ to $150 \mathrm{~mm}$ & $200 \mathrm{~mm}$ to $2000 \mathrm{~mm}$ \\
\hline Type of plant & Sedum and grass & Trees and shrubs \\
\hline Irrigation & Limited & Regular \\
\hline Vegetation layer & Thinner & Thicker \\
\hline $\begin{array}{c}\text { Technical expertise or practical } \\
\text { experience requirement }\end{array}$ & Minimal & Higher \\
\hline Structural support & Lower & Greater \\
\hline
\end{tabular}

Table 1 Characteristics of Extensive and Intensive Green Roofs

The initial cost for installing an extensive green roof is about US $\$ 8-20 / \mathrm{ft}^{2}$ (AUD $90220 / \mathrm{m}^{2}$ ) while installing an intensive green roof is about US\$15-25/ $\mathrm{ft}^{2}$ (AUD $165-275 / \mathrm{m}^{2}$ ) (Great Lakes Water Institute - School of Freshwater Sciences - University of Wisconsin Milwaukee 2011). This cost estimation includes design and specification, project administration, site review, re-roofing with root-repelling membrane, drainage, filtering, paving, growing medium, plants, installation, and irrigation system.

Constructing green roofs brings a lot of benefits to the environment, which include: (i) reducing urban island heat effect (Jenrick 2005); (ii) improving air quality by converting carbon dioxide into oxygen (Grant et al. 2003); (iii) reducing noise (Lagstrom 2004); (iv) reducing water runoff speed (Rowe et al. 2005); (v) increasing wildlife and biodiversity (Gedge and Frith 2004); (vi) increasing roof life by reducing thermal stress in the membrane (Jenrick 2005); (vii) increasing energy efficiency by reducing the amount of solar heat energy absorbed by the roof below through evapotranspiration by plants (Jenrick 2005); (viii) reducing roof maintenance (Cutlip 2006); (ix) improving visual amenity (Gedge and Frith $2004)$; and ( $x$ ) improving health by reducing stress and providing cleaner air (Gedge and Frith 2004).

Tam, V W Y et al. (2011) 'Applications of extensive green-roof systems in contributing to sustainable development in densely populated cities: a Hong Kong study', Australasian Journal of Construction Economics and Building, 11 (1) 1525 
Both green roof systems have the above benefits. However, the extensive green roofs are often less visually pleasing because of fewer types of plants are used (Getter and Rowe 2006) but have higher cost savings due to less care as compared to intensive green roofs. Table 2 summarizes the benefits of the intensive and extensive green roof systems.

\begin{tabular}{|l|c|c|}
\hline & Intensive green roof & Extensive green roof \\
\hline Reduced urban island heat effect & $\checkmark$ & $\checkmark$ \\
\hline Improved air quality & $\checkmark$ & $\checkmark$ \\
\hline Reduced noise absorption & $\checkmark$ & $\checkmark$ \\
\hline Reduced water runoff & $\checkmark$ & $\checkmark$ \\
\hline Improved wildlife and biodiversity & $\checkmark$ & $\checkmark$ \\
\hline Increased roof life & $\checkmark$ & $\checkmark$ \\
\hline Increased energy efficiency & $\checkmark$ (Lower) & $\checkmark$ (Higher) \\
\hline Cost savings & $\checkmark$ (Higher) & $\checkmark$ (Lower) \\
\hline Maintenance costs & $\checkmark$ (Higher) & $\checkmark$ (Lower) \\
\hline Improved visual amenity & $\checkmark$ & $\checkmark$ \\
\hline Improved health & & \\
\hline
\end{tabular}

Table 2 Benefits of Intensive and Extensive Green Roof Systems

Although there are many benefits for constructing green roof systems, the extensive green roofs are still not commonly used in Hong Kong. The major constraints for the use of extensive green roof systems are:

(i) Lack of knowledge and awareness: The intensive green roofs have widespread used in Hong Kong but this is not the case with the extensive green roofs. The main reason is lack of knowledge and awareness of extensive green roofs. Intensive green roofs are similar to growing plants on the ground, only at a higher level, so it is easier to develop than the extensive green roofs. Due to a lack of government use of extensive green roofs in their green roof projects, neither the public nor the private sectors are familiar with the extensive green roof systems (Urbis Limited 2007).

(ii) Lack of incentive: Since the government lacks knowledge and awareness of extensive green roofs, incentives provided by the government to developers for constructing extensive green roofs is inadequate (Urbis Limited 2007).

(iii) Increased design cost: It is necessary to properly design a suitable roof base for the extensive green roofs. Design cost may increase with the weight of the extensive green roof systems (Urbis Limited 2007).

(iv) Structural loading: Roof structural loading is a main factor determining the viability and cost of green roof installation, particularly for extensive green roofs. Retrofitting an existing roof may not be feasible if the structural capacity of the roof is inadequate (Hui and Chan 2008) (Urbis Limited 2007).

(v) Technical issues and risks associated with uncertainty: In the construction of the extensive green roofs, some technical issues, such as design, layer between waterproofing layer and plant layer, wind load and structural load, need to be considered. Arrangement is required for preparing for future maintenance (Urbis Limited 2007).

\section{The Existing Applications of Green Roof Projects Used in Hong Kong}

There are some governmental buildings such as governmental offices, schools and hospitals which have adopted green roof systems in Hong Kong. According to the Legislation Council meeting on 15 November 2006 (Legislative Council 2006), 53 buildings having adopted green roof features, with the details in Table 3 and Table 4.

Tam, V W Y et al. (2011) 'Applications of extensive green-roof systems in contributing to sustainable development in densely populated cities: a Hong Kong study', Australasian Journal of Construction Economics and Building, 11 (1) 15- 


\begin{tabular}{|c|c|}
\hline Type of buildings & Number of projects \\
\hline School & 16 \\
\hline Office building & 17 \\
\hline Hospital & 7 \\
\hline Community facilities & 9 \\
\hline Governmental quarters & 4 \\
\hline Total & 53 \\
\hline
\end{tabular}

Table 3 Various Types of Completed Buildings with Green Roof Features from 2001 to 2006 (Legislative Council 2006)

\begin{tabular}{|c|c|}
\hline Green roof features & Number of projects \\
\hline Soil layer planting on rooftop surface & 45 \\
\hline Pot planting & 2 \\
\hline Soil layer planting on rooftop surface and pot planting & 6 \\
\hline Total & 53 \\
\hline
\end{tabular}

Table 4 A Breakdown of Direct Soil Planting on Rooftop Surface and/or Pot Planting from 2001 to 2006 (Legislative Council 2006)

The main types of completed buildings with green roof features are schools and office buildings. Most of the green roof systems use soil layer planting on rooftop surface. However, there is no statistics for the total number of green roofs with extensive green roofs and intensive green roofs in Hong Kong buildings. Table 5 shows some examples of buildings which have applied green roofs in Hong Kong.

\begin{tabular}{|l|l|c|c|}
\hline $\begin{array}{c}\text { Type of } \\
\text { building }\end{array}$ & \multicolumn{1}{|c}{\begin{tabular}{c}
\multicolumn{1}{c}{ Green roof project } \\
Government \\
buildings
\end{tabular}} & $\begin{array}{c}\text { Intensive } \\
\text { green roof }\end{array}$ & $\begin{array}{c}\text { Extensive } \\
\text { green roof }\end{array}$ \\
\hline & North Point Government Offices, North Point & $\checkmark$ \\
\hline & New EMSD Headquarters, Kowloon City & $\checkmark$ & \\
\hline & $\begin{array}{l}\text { Podium Garden, Civil Engineering and Development } \\
\text { Department Headquarters, Ho Man Tin }\end{array}$ & $\checkmark$ & \\
\hline & Primary School at Sze Mei Street. San Po Kong & & \\
\hline & Shun Lee Department Quarter, Shun Lee & $\checkmark$ & \\
\hline & Kwai Chung Ambulance Depot, Kwai Chung & $\checkmark$ & \\
\hline & Podium Garden, Tin Shui Wai Area 102, Tin Shui Wai & $\checkmark$ & \\
\hline & Fanling Magistracy Building, Fanling & $\checkmark$ & \\
\hline & Science Park, Building 9, New Territories & $\checkmark$ & \\
\hline \multirow{2}{*}{$\begin{array}{l}\text { Residential } \\
\text { buildings }\end{array}$} & Eastern Harbour Crossing Site Phase 3, Yau Tong & & \\
\hline $\begin{array}{l}\text { Commercial } \\
\text { buildings }\end{array}$ & International Finance Centre II, Central & $\checkmark$ & \\
\hline & Pacific Place I and II, Admiralty & $\checkmark$ & \\
\hline & $\begin{array}{l}\text { The Hongkong and Shanghai Banking Corporation } \\
\text { Limited, Central }\end{array}$ & $\checkmark$ & \\
\hline
\end{tabular}

Table 5 Examples of Hong Kong Green Roof Projects (Urbis Limited 2007)

From the above cases, it can be seen that applications of the extensive green roofs are limited in Hong Kong. Furthermore, the original designs of old buildings were not planned for green roofs in the future, and the extra loading may not be possible to accommodate. There are also unauthorized building works on top of the roofs of existing buildings. This will restrict

Tam, V W Y et al. (2011) 'Applications of extensive green-roof systems in contributing to sustainable development in densely populated cities: a Hong Kong study', Australasian Journal of Construction Economics and Building, 11 (1) 1525 
the potential for construction of green roofs. In addition, some roof areas may be owned by different owners, making it difficult to make arrangement among owners for constructing green roofs.

\section{Research Methodologies}

To investigate the familiarity of the public of extensive green roofs, and constraints on using extensive green roofs on existing buildings in Hong Kong, a survey was conducted. 600 questionnaires were sent to university academics, government departments, consultants, contractors and general public. 426 respondents were received with a response rate of about $71 \%$.

Relative importance index (RII) as used for the data analysis in this paper, is shown in Eq. (1).

$$
\text { Relative importance index }(\mathrm{RII})=\frac{\sum w}{A N},(0 \leq R I I \leq 1) \quad \text { Eq. (1) }
$$

where $\mathrm{w}$ is the sum of individual scores given to each factor by the respondents and ranging from 1 to 5 where ' 1 ' is 'strongly disagree' and ' 5 ' is 'strongly agree'; A the possible highest score for each factor (i.e. 5 in this case); and $\mathrm{N}$ the total number of responses concerning that factor.

Spearman's rank correlation test is used to measure the level of agreement among different groups of respondents. The opinion of different groups of respondents is analyzed and compared by mean score.

After receiving the questionnaire responses, individual structured interviews are arranged with twenty respondents, selected from different categories and different disciplines of respondents. The interviews are intended for gathering further comments; elaboration and interpretation on the results obtained from the questionnaire.

\section{Results and Discussions}

The respondents are categorized as government departmental staff (34.1\%), contractors $(20.3 \%)$, consultants $(15.9 \%)$, academia $(19 \%)$ and others $(10.7 \%)$ under five different disciplines, including architecture (14\%), surveying (40\%), engineering (13\%), education (19\%) and others (14\%).

Table 6 summarizes the existing and future development of green roof systems. All respondents are not green roof users and majority of the respondents are not involved with any green roof project. The majority of the respondents did not agree that an extensive green roof system is widely used for the existing buildings, in which they argue that one of the main problems is that it is not sufficient promoted by the government. Although the green roof systems are not widely adopted, the respondents still agree that the applications of extensive green roof systems are feasible for existing buildings (about 96.6\%) and they also support the implementation of extensive green roof systems for the existing buildings (about $96.1 \%)$ and the construction of an extensive green roof on the building where they live (about 85\%).

Based on the previous literatures (Koppany 2002; Grant et al. 2003; Liu and Baskaran 2003; Gedge and Frith 2004; Lagstrom 2004; Ngan 2004; Worden et al. 2004; Jenrick 2005; Rowe et al. 2005; Cutlip 2006; Getter and Rowe 2006; Legislative Council 2006; Urbis Limited 2007), benefits from implementing extensive green roof systems are: (i) reduced urban island heat effect; (ii) improved air quality; (iii) improved noise absorption; (iv) reduced water runoff speed; (v) increased wildlife and biodiversity; (vi) prolonged roof life; (vii) improved energy efficiency; (viii) cost saving; (ix) reduced roof maintenance; (x) improved visual amenity; (xi) improved public health; and (xii) increased amenity areas.

Tam, V W Y et al. (2011) 'Applications of extensive green-roof systems in contributing to sustainable development in densely populated cities: a Hong Kong study', Australasian Journal of Construction Economics and Building, 11 (1) 15- 


\begin{tabular}{|c|c|}
\hline & Percentage \\
\hline \multicolumn{2}{|l|}{ Green roof user } \\
\hline Yes & 0.0 \\
\hline No & 100.0 \\
\hline \multicolumn{2}{|c|}{ Green roof project involvement } \\
\hline Yes & 3.0 \\
\hline No & 97.0 \\
\hline \multicolumn{2}{|c|}{ Do you agree extensive green roof systems are widely used for the existing buildings? } \\
\hline Strongly agree & 0.0 \\
\hline Agree & 5.2 \\
\hline Neutral & 15.5 \\
\hline Disagree & 43.5 \\
\hline Strongly disagree & 35.8 \\
\hline \multicolumn{2}{|c|}{$\begin{array}{l}\text { Do you agree the government has taken sufficient measures to promote the application of } \\
\text { extensive green roof systems for the existing buildings? }\end{array}$} \\
\hline Strongly agree & 0.0 \\
\hline Agree & 2.2 \\
\hline Neutral & 15.1 \\
\hline Disagree & 51.7 \\
\hline Strongly disagree & 31.0 \\
\hline \multicolumn{2}{|c|}{ Do you think the application of extensive green roof systems for the existing buildings is feasible? } \\
\hline Yes & 96.6 \\
\hline No & 3.4 \\
\hline \multicolumn{2}{|c|}{ Do you support the implementation of the extensive green roof systems for the existing buildings? } \\
\hline Yes & 96.1 \\
\hline No & 3.9 \\
\hline \multicolumn{2}{|c|}{ Do you support to construct an extensive green roof of the building where you live in? } \\
\hline Yes & 85.0 \\
\hline No & 15.0 \\
\hline
\end{tabular}

Table 6: The Existing and Future Development of the Extensive Green Roof Systems

The survey results in Table 7, show that most of the respondents agree that benefits can be gained by implementing extensive green roof systems. Improving visual amenity ranks first with the RII of 0.889 . Green roofs can increase green features in the limited land areas. The interviewees also highlight that green areas can always improve the visual impression of the environment, and the same applies to extensive green roof systems. Urban island heat effect and air quality can also be improved due to reflection of direct sunlight and photosynthesis of plants respectively which ranked as the second and third major benefits respectively from the survey results.

However, reducing roof maintenance is ranked as the least beneficial, with the RII of 0.572 . One of the interviewees argues that he is unsure about the low maintenance for the extensive green roof systems, which may depends on the selection of plants. The maintenance for extensive green roof systems may shift from the roof itself to the plants.

The authors are currently conducting a separate study on cost saving from energy in implementing green roof systems. It has a preliminary results showing that there is about 50 per cent energy cost reduction in the initial set-up of the roof. Detailed analysis, including life cycle costing and payback period, will be reported in a separate paper in the near future.

The different groups of respondents have similar views on the benefits of implementing extensive green roof systems with no significant difference indicated by Spearman's rank correlation analysis. Although the implementation of extensive green roof systems for the existing buildings may have benefits, it also has some constraints. Fourteen constraints are highlighted in the literature (Koppany 2002; Grant et al. 2003; Liu and Baskaran 2003;

Tam, V W Y et al. (2011) 'Applications of extensive green-roof systems in contributing to sustainable development in densely populated cities: a Hong Kong study', Australasian Journal of Construction Economics and Building, 11 (1) 1525 
Gedge and Frith 2004; Lagstrom 2004; Ngan 2004; Worden et al. 2004; Jenrick 2005; Rowe et al. 2005; Cutlip 2006; Getter and Rowe 2006; Legislative Council 2006; Urbis Limited 2007): (i) lack of knowledge; (ii) lack of awareness; (iii) lack of incentive from the government to developers; (iv) lack of incentive from the government to owners of existing buildings; (v) lack of promotion by the government; (vi) increase in design cost; (vii) increase in strengthening cost to withstand additional structural loading; (viii) increase in construction cost; (ix) increase in maintenance cost; (x) increase in structural loading; (xi) design difficulties; (xii) difficulties in laying waterproofing payer and plant layer; (xiii) withstand wind load; and (xiv) regular maintenance.

\begin{tabular}{|l|c|c|c|c|c|c|c|}
\hline \multicolumn{1}{|c|}{ Benefits } & $\begin{array}{c}\text { Strongly } \\
\text { disagree }\end{array}$ & Disagree & Neutral & Agree & $\begin{array}{c}\text { Strongly } \\
\text { Agree }\end{array}$ & RII & Ranking \\
\hline $\begin{array}{l}\text { Reduce urban island } \\
\text { heat effect }\end{array}$ & 0.0 & 0.0 & 23.1 & 43.3 & 33.6 & 0.838 & 2 \\
\hline Improve air quality & 0.0 & 3.3 & 21.2 & 46.6 & 28.9 & 0.819 & 3 \\
\hline Improve noise absorption & 0.0 & 16.4 & 44.8 & 28.9 & 9.9 & 0.678 & 7 \\
\hline $\begin{array}{l}\text { Reduce water runoff } \\
\text { speed }\end{array}$ & 0.0 & 20.7 & 59.9 & 18.1 & 1.3 & 0.612 & 10 \\
\hline $\begin{array}{l}\text { Increase wildlife and } \\
\text { biodiversity }\end{array}$ & 6.9 & 23.7 & 44.8 & 21.6 & 3.0 & 0.592 & 11 \\
\hline Prolong roof life & 5.6 & 16.8 & 36.7 & 36.2 & 4.7 & 0.648 & 8 \\
\hline $\begin{array}{l}\text { Improve energy } \\
\text { efficiency }\end{array}$ & 0.9 & 3.0 & 28.5 & 44.8 & 22.8 & 0.787 & 6 \\
\hline Cost saving & 3.9 & 27.6 & 44.3 & 19.0 & 5.2 & 0.600 & 9 \\
\hline $\begin{array}{l}\text { Reduce roof } \\
\text { maintenance }\end{array}$ & 7.3 & 32.8 & 35.8 & 20.7 & 3.4 & 0.572 & 12 \\
\hline Improve visual amenity & 0.0 & 0.9 & 9.4 & 43.1 & 46.6 & 0.889 & 1 \\
\hline Improve public health & 0.0 & 4.7 & 16.4 & 62.1 & 16.8 & 0.798 & 5 \\
\hline Increase amenity areas & 0.9 & 3.9 & 21.1 & 51.3 & 22.8 & 0.798 & 4 \\
\hline
\end{tabular}

Table 7 Benefits in Implementing Extensive Green Roof Systems

From the survey results shown in Table 8, most of the respondents agree that there are major constraints in the implementation of extensive green roof systems. It is found that lack of promotion from the government and lack of incentives from the government to owners of existing buildings rank as the major constraints with the RII of 0.826 and 0.808 respectively. The interviewees explain that the adoption of innovative facilities needs to be promoted and supported by the government at the early stage of development; otherwise, the industry will adopt a wait-and-see attitude before implementation. When the industry did not have experience of innovative facilities, they consider it risky for the long term.

Maintenance is a long term process and continuous maintenance cost is normally required. Therefore, increased maintenance cost and regular maintenance for the implementation of extensive green roof systems are ranked as the third and fifth major constraints with RII of 0.799 and 0.765 respectively.

From the survey results, design for extensive green roof systems is not a major constraint for the implementation, which ranks lowest. The interviewees explained that architectural design is not much different for a green roof building compared to a non-green roof building, particular with an extensive green roof design not using big trees. This can also explain why ability to withstand wind load did not rank as one of the major constraints.

Tam, V W Y et al. (2011) 'Applications of extensive green-roof systems in contributing to sustainable development in densely populated cities: a Hong Kong study', Australasian Journal of Construction Economics and Building, 11 (1) 15 25 
The different groups of respondents, have similar views on the major constraints in the implementation of extensive green roof systems with no significant value from the Spearman's rank correlation analysis.

\begin{tabular}{|c|c|c|c|c|c|c|c|}
\hline Constraints & $\begin{array}{l}\text { Strongly } \\
\text { disagree }\end{array}$ & Disagree & Neutral & Agree & $\begin{array}{c}\text { Strongly } \\
\text { Agree }\end{array}$ & RII & Ranking \\
\hline Lack of knowledge & 0.0 & 4.3 & 29.3 & 44.4 & 22.0 & 0.784 & 6 \\
\hline Lack of awareness & 0.0 & 4.3 & 28.0 & 45.3 & 22.4 & 0.787 & 4 \\
\hline $\begin{array}{l}\text { Lack of incentive from the } \\
\text { government to } \\
\text { developers }\end{array}$ & 0.0 & 9.9 & 29.2 & 40.6 & 20.3 & 0.758 & 9 \\
\hline $\begin{array}{l}\text { Lack of incentive from the } \\
\text { government to building } \\
\text { owners for the existing } \\
\text { building }\end{array}$ & 0.0 & 4.3 & 22.8 & 45.7 & 27.2 & 0.808 & 2 \\
\hline $\begin{array}{l}\text { Lack of promotion from } \\
\text { the government }\end{array}$ & 0.0 & 5.2 & 17.6 & 44.4 & 32.8 & 0.826 & 1 \\
\hline Increase in design cost & 1.7 & 6.0 & 27.2 & 51.7 & 13.4 & 0.753 & 10 \\
\hline $\begin{array}{l}\text { Increase in strengthening } \\
\text { cost in withstanding } \\
\text { additional structural } \\
\text { loading }\end{array}$ & 0.0 & 7.8 & 25.8 & 50.0 & 16.4 & 0.765 & 7 \\
\hline $\begin{array}{l}\text { Increase in construction } \\
\text { cost }\end{array}$ & 0.0 & 5.2 & 32.7 & 45.3 & 16.8 & 0.763 & 8 \\
\hline $\begin{array}{l}\text { Increase in maintenance } \\
\text { cost }\end{array}$ & 0.0 & 3.0 & 21.5 & 56.5 & 19.0 & 0.799 & 3 \\
\hline $\begin{array}{l}\text { Increase in structural } \\
\text { loading }\end{array}$ & 0.9 & 12.1 & 28.4 & 44.8 & 13.8 & 0.732 & 11 \\
\hline Design difficulties & 3.9 & 24.6 & 40.0 & 26.3 & 5.2 & 0.621 & 14 \\
\hline $\begin{array}{l}\text { Difficulties in laying } \\
\text { waterproofing layer and } \\
\text { plant layer }\end{array}$ & 2.2 & 10.3 & 29.3 & 44.8 & 13.4 & 0.728 & 12 \\
\hline Withstand wind load & 2.2 & 21.6 & 34.9 & 33.2 & 4.7 & 0.625 & 13 \\
\hline Regular maintenance & 1.3 & 3.4 & 18.5 & 55.2 & 18.1 & 0.765 & 5 \\
\hline
\end{tabular}

Table 8: Constraints in Implementing Extensive Green Roof Systems

To encourage the implementation of extensive green roofs, nine measures are suggested based on the literatures (Koppany 2002; Grant et al. 2003; Liu and Baskaran 2003; Gedge and Frith 2004; Lagstrom 2004; Ngan 2004; Worden et al. 2004; Jenrick 2005; Rowe et al. 2005; Cutlip 2006; Getter and Rowe 2006; Legislative Council 2006; Urbis Limited 2007): (i) The government provides incentive to developers; (ii) The government provides incentive to owners of existing buildings; (iii) The government offers extra floor area bonus to the developers who construct certain green roof areas; (iv) Amount of green area compulsory in open space under property development regulations (v) Percentage of prescribed green space compulsory on roofs for property development projects; (vi) Green roof construction sets as a statutory requirement under certain conditions such as roof area, building size, use, etc; (vii) Setup guidelines for developers / contractors; (viii) Building with specified area of impervious surface is required to construct green roofs for reducing storm water pollution and flow rates; and (ix) Educate public to enhance the awareness of the importance of green roofs.

In Table 9, it can be seen that setting up guidelines for developers / contractors to construct green roofs, educate the public to be aware of the importance of green roofs, and the government providing incentives to developers and building owners are the best measures for reducing constraints on the implementation of green roof systems. However, buildings with a specified area of impervious surface required to construct green roofs, percentage of

Tam, V W Y et al. (2011) 'Applications of extensive green-roof systems in contributing to sustainable development in densely populated cities: a Hong Kong study', Australasian Journal of Construction Economics and Building, 11 (1) 1525 
prescribed green roofs and amount of green area compulsory on roof for property development projects and green roof construction sets as a statutory requirement are not highly ranked as measures to improve the constraints to the implementation, and rank last, seventh, sixth and fifth respectively. It should be noted that voluntary approaches are are preferred to mandatory approaches in improving the implementation of extensive green roof systems. The interviewees also point out that mandatory requirements can force the industry to quickly implement the suggested approaches; however, it can cause a lot of long term problems for the ineffective and inefficient implementation. This may ultimately delay the successfully implement.

Different groups of respondents have similar views on the major issues in the implementation of extensive green roof systems with no significant differences indicated by Spearman's rank correlation analysis.

\begin{tabular}{|c|c|c|c|c|c|c|c|}
\hline Measures & $\begin{array}{l}\text { Strongly } \\
\text { disagree }\end{array}$ & Disagree & Neutral & Agree & $\begin{array}{l}\text { Strongly } \\
\text { Agree }\end{array}$ & RII & Rank \\
\hline $\begin{array}{l}\text { The government } \\
\text { provides incentive to } \\
\text { developers }\end{array}$ & 3.9 & 9.1 & 18.5 & 47.8 & 20.7 & 0.760 & 4 \\
\hline $\begin{array}{l}\text { The government } \\
\text { provides incentive to } \\
\text { owners of existing } \\
\text { buildings }\end{array}$ & 3.0 & 5.6 & 22.9 & 47.8 & 20.7 & 0.771 & 3 \\
\hline $\begin{array}{l}\text { The government offers } \\
\text { extra floor area bonus to } \\
\text { developers who } \\
\text { construct certain green } \\
\text { roof areas }\end{array}$ & 6.5 & 15.5 & 20.7 & 37.9 & 19.4 & 0.711 & 8 \\
\hline $\begin{array}{l}\text { Amount of green area } \\
\text { compulsory in an open } \\
\text { space for property } \\
\text { development projects }\end{array}$ & 1.3 & 15.1 & 20.7 & 45.7 & 17.2 & 0.740 & 6 \\
\hline $\begin{array}{l}\text { Percentage of } \\
\text { prescribed green space } \\
\text { compulsory on roof for } \\
\text { property development } \\
\text { projects }\end{array}$ & 0.4 & 17.2 & 24.7 & 37.9 & 19.8 & 0.734 & 7 \\
\hline $\begin{array}{l}\text { Green roof made } \\
\text { statutory requirement } \\
\text { under certain conditions. }\end{array}$ & 0.9 & 12.9 & 26.7 & 39.2 & 20.3 & 0.745 & 5 \\
\hline $\begin{array}{l}\text { Setup guidelines for } \\
\text { developers /contractors }\end{array}$ & 0.0 & 2.2 & 10.7 & 48.7 & 38.4 & 0.864 & 1 \\
\hline $\begin{array}{l}\text { Building with specified } \\
\text { area of impervious } \\
\text { surface required to } \\
\text { construct green roofs for } \\
\text { reducing storm water }\end{array}$ & 3.0 & 6.9 & 53.4 & 27.6 & 9.1 & 0.679 & 9 \\
\hline $\begin{array}{l}\text { Educate public to be } \\
\text { aware of the importance } \\
\text { of green roofs }\end{array}$ & 0.4 & 2.2 & 14.6 & 49.6 & 33.2 & 0.843 & 2 \\
\hline
\end{tabular}

Table 9: Measures for Reducing Constraints in Implementing Extensive Green Roof Systems

\section{Practical implications}

Based on the survey results and interview discussions, if the aim is to increase the benefits of a wider adoption of extensive green roofs for existing buildings and future development, the following recommendations would be necessary.

Tam, V W Y et al. (2011) 'Applications of extensive green-roof systems in contributing to sustainable development in densely populated cities: a Hong Kong study', Australasian Journal of Construction Economics and Building, 11 (1) 1525 


\section{Subsidization}

Applications of extensive green roof systems to the existing buildings are still at the early stage for the industry. If the government aims to promote the use of extensive green roof systems it may need to counter current uncertainty about their effectiveness and subsidy industry and public for the construction of extensive green roof systems for existing and new buildings and buildings.

\section{Setup guidelines}

At present, there is no clear guideline provided to the industry and public on extensive green roof systems. To promote them, there should be definitions of different green roof systems and basic components of green roof systems should be included in the guidelines as well as information on the structures of green roof systems and functions of each component. The guidelines should also include specifications for design, construction and maintenance.

\section{Technical support}

The Government could benefit from a designated department to monitor applications of extensive green roof systems and provide technical support to industry on effective use of extensive green roof systems.

\section{Education}

To promote extensive green roof systems the government could act as a leader in using extensive green roof systems for governmental buildings. Site visits, seminars and mass media could also be organized to disseminate knowledge to industry and public.

\section{Conclusion}

This paper examined the experience of using green roofs in Hong Kong. Survey and interviews reveled that although extensive green roof systems are not widely adopted, the application of extensive green roof systems is still feasible for the existing buildings. The industry generally also supports the implementation of extensive green roof systems for the existing buildings. It was found that the main benefits can be gained from the implementation of extensive green roofs are improving visual amenity, reducing urban island heat effect and improving air quality. However, lack of promotion from the government and lack of incentives from the government to owners for the existing buildings were found to be the major constraints in the implementation. To improving the implementation of the extensive green roof systems, market rather than mandatory approaches are suggested. Recommendations were suggested for improving the existing and future development of the implementation.

\section{References}

Cutlip, J. (2006) Green roofs: a sustainable technology, Docstoc

Gedge, D. \& Frith, M. (2004) Green roofs benefits and cost implications, Birmingham City Council, United Kingdom

Getter, K.L. \& Rowe, D.B. (2006) 'The role of green roofs in sustainable development', Hort Science, 41 (5), 1276-1285

Grant, G., Engleback, L., Nicholson, B., Gedge, D., Frith, M. \& Harvey, P. (2003) Green roofs: their existing status and potential for conserving biodiversity in urban areas, Report Number 498, English Nature, Northminister House, Peterborough PE1 1UA, England

Hui, S.C.M. \& Chan, H.M. (2008) 'Development of modular green roofs for high-density urban cities', World Green Roof Congress, London, United Kingdom, 25-31

Jenrick, K. (2005) Green roofs: a horticulural perspective, Ritak Vitabuc Gardens, Kew, United Kingdom

Tam, V W Y et al. (2011) 'Applications of extensive green-roof systems in contributing to sustainable development in densely populated cities: a Hong Kong study', Australasian Journal of Construction Economics and Building, 11 (1) 15- 
Koppany, A. (2002) Green roofs in the city environment, Department of Architecture and Building Construction, Faculty of Building and Environmental Engineering, Sz'echenyi Istv'an University of Applied Sciences, Hungary

Lagstrom, J. (2004) Do extensive green roofs reduce noise?, International Green Roof Institute

Legislative Council (2006) Offocial record of proceedings Wednesday, 15 November 2006, the Council met at Eleven o'clock, Legislative Council, Hong Kong Special Administrative Region

Liu, K. \& Baskaran, B. (2003) 'Thermal performance of green roofs through field evaluation', Proceedings for the First North American Green Roofs Infrastructure Conference, Awards and Trade Show, Chicago, United States of America, 1-10

Ngan, G. (2004) Green roof policy: tools for encouraging sustainable design, British Columbia Society of Landscape Architects, United Kingdom

Rowe, D.B., Monterusso, M.A. \& Rugh, C.L. (2005) 'Evaluation of Sedum spp. and Michigan native taxa for green roof applications', Proceedings of 3rd North American Green Roof Conference: Greening Rooftops for Sustainable Communities, Washington, DC, United States, 469-481

Urbis Limited (2007) Study on green roof application in Hong Kong, Urbis Limited, Architectural Services Department

Worden, E., Guidry, D., Ng, A.A. \& Schore, A. (2004) Green roofs in urban landscapes, Department of Environmental Horticulture, University of Florida, United States 